\title{
Vladimir Jankélévitch
}

Intro

\section{LIS NORUP OG VAGN LYHNE}

I sine sidste år skulle Vladimir Jankélévitch (1903-1985) opleve et formeligt gennembrud, også i forhold til det store publikum. Dette gennembrud lod sig til en vis grad forklare ud fra det opgør, der i 70'erne og 80'erne blev foretaget med oplysningstraditionen, med marxismen som metode og ideologi og med socialismen som politisk og moralsk ideal. Jankélévitch stod selv indifferent over for de former, dette opgør antog, men det er åbenbart, at der i hans forfatterskab er repræsenteret ideer, tankeformer og måder at gestalte disse på, der havde affinitet til dem, der nu skulle gøre sig gældende.

Jankélévitch forholder sig - især i sit senere forfatterskab - kritisk til de dualismer, der op gennem den europæiske filosofi er blevet begrebsliggjort i modsætninger som essens-accidens, idéverden-fænomenverden, det indre-det ydre og Wesen-Erscheinung. Selv om han anerkender sådanne modsætninger som nødvendige for perceptionen og erkendelsen, for individets orientering i verden, afviser han, at første del af modsætningsparret - in casu essens, idé, det indre osv. - skulle være besat med en særlig sandhed og væsentlighed, der genererer sin modsætning i dens lavere grad af virkelighed. Det eksisterende lader sig nok bestemme $i$ kategorier og niveauer og falder på ingen måde fra hinanden i den rene atomisme, men disse niveauer er forskydelige og udskiftelige i betydning og status.

Opgivelsen af dualisme-tænkningen i dens klassiske form åbner for en rehabilitering af sansernes verden, den empiriske verden. Den især i den tyske idealisme indeholdte fordring om en mediering mellem dele, overskridelse af afstande afsvækkes eller falder bort, og fænomenologiens 
krav på en position som overgribende metode (Sartre, Merleau-Ponty) - i Frankrig stærkt fremhjulpet af Alexandre Kojèves Hegel-læsninger i 30'erne - benægtes. Samtidig muliggør bevarelsen af niveautænkningen, hævdelsen af en dynamisk forskydning mellem områder og ting af forskellig væsentlighed den fintmærkende kritiske registrering, analyse og den dermed sammenhængende valorisering. Det eksisterende kræver sin konkrete undersøgelse og bedømmelse og lader sig ikke gribe og begribe gennem mekaniske koblinger mellem fænomener eller områder af forskellig grader af virkelighed og moralsk-sædelig betydning. Således kan det, der fremtræder som mest udvendigt og tomt - det virtuose, det strålende, det spillende og rapsodiske - vise sig som alvorligt og sandt, mens omvendt det dybeste og åndeligste kan afsløre sig som forkasteligt og falsk.

I denne filosofi uden absolutter er det flygtige, det uhåndgribelige, det forsvindende bestandigheden. Tiden, som Jankélévitch under påvirkning af Bergson analyserer igen og igen, er i sin irreversibilitet det nådesløse vilkår, men giver samtidig mennesket mulighed for at gribe hvert øjeblik i dets rigdom, før det for altid er tabt. - Fraværet af en endegyldig sandhed er sand, begæret efter at bestemme sandheden i dens ubetingethed "en dogmatisk utopi". Det essentielle er noget, der måske ikke findes, som aldrig vil kunne fastholdes, men ikke desto mindre er det det mest fornødne, der mærkes, sanses, erkendes som Le Je-ne-sais-quoi et le Presque-rien, titlen på Jankélévitchs bog fra 1957. Derfor findes i hans værk en række referencer, der har været sekundære i den protestantiske verdens filosofi, henvisninger til Saint François de Sales, Baltasar Gracián, Fénelon - hofmanden i en verden af agilitet, vid, lethed, délicatesse, men også mystikeren. Han higer ikke mod tilværelsens urgrund, han synker ikke ned i sindets nat, men fortaber sig i betragtningen af verden i dens underfulde fakticitet, $\mathrm{i}$ "mysterier i fuldt lys, evidencens mysterium".

Selv udgår Jankélévitch i sine bøger ofte fra dette næsten intet, fra et enkelt ord, som er udgangspunkt og titel: L'Ironie, L'Alternative, Le Mal, Du Mensonge, La Mauvaise 
Conscience, Le Pardon, La Mort. Og med særlig kærlighed omkredser han det i sit store musikfilosofiske forfatterskab, der fokuserer på - og voldsomt opvurderer - den franske musik, specielt klaverlitteraturen, efter 1870 (Fauré, Debussy, Ravel, Satie m.fl.), en dirrende, let, kapriciøs musik, baseret på moderne formprincipper, forskellige fra tidligere tiders fuga og sonate, der bydende organiserer og beslaglægger rummet. Disse undertiden enorme skrifter udvikler sig i mindre bevægelser, der samler sig i store arabesker, altid understøttet af en omfattende viden om europæisk filosofi og kunst fra antikken og fremefter, der ubesværet hentes frem og integreres i analysen. Indtil dette jeg-ved-ikke-hvad eller næsten-intet er omcirklet og gennemstrejfet i det omfang, der måtte være ønskeligt og muligt, og bogen ikke når sin afslutning, men slutter. Synligt i skriften er da dette bestemte ubestemte, som Jankélévitch kalder charme.

Det er ynden i den analytiske praksis, der kendetegner Jankélévitchs bøger, som den kendetegnede ham som person og det uanset sværhedsgraden af mange af hans tekster. Men hans værk er ikke forbundet med nogen glad nihilisme og er, hvor sikkert det end søger sin plaisir, ikke forfalden til nogen form for hedonisme, men tværtimod gennemtrængt af moralsk strenghed, kravet om menneskers hengivelse til hinanden, opofrelse for hinanden og kamp for hinandens ret. I modsætning til de fleste af sine kolleger på Sorbonne lod han sig ikke forskrække af de politiske og moralske aspekter af 68oprøret og oplevede begivenhederne som en revolution i en autentisk fransk tradition, et gennembrud i forholdet mellem lærere og studenter. Selv af jødisk oprindelse havde han under krigen deltaget i modstandskampen og udtaler sig i interviews med grum spot om de engagerede filosoffer, de frihedsapostle, der under besættelsen skrev disputatser om friheden, mens friheden stod på spil. Dybt fortrolig med tysk filosofi - hans disputats omhandlede den sene Schelling - nægtede han efter krigen, chokeret og forbitret over jødeudryddelserne, at beskæftige sig med tysk kultur overhovedet. Ud røg Bach, Beethoven og Wagner, hvis musik rent faktisk afspejlede 
det filosofiske univers, han afskrev - samme vej gik Hegel, Husserl og endelig Heidegger, hvis filosofiske galimatias han indrangerede på linje med Værnemagtsopråb og den Schubert-musik, der hørtes, mens jøderne blev drevet ind i gaskamrene i Auschwitz.

Dekadencen er et uddrag af Jankélévitchs artikel La Décadence, trykt i tidsskriftet Revue de Métaphysique et de Morale no 4, 1950.

Dekadencen bestemmes i artiklen primært som et bevidsthedsfænomen, som en for vidt dreven introspektion, en bevidsthedens selvbevidsthed og selvrefleksion, der har mistet en naturlig og sand forbindelse til det, der ligger udenfor jeg'et: objekternes og det levende livs verden, handlingens og forandringens verden. Det er denne refleksion over tankens bevægelser, der for Jankélévitch er den dekadente bevidstheds virkelige ulykke, og som avler dens serier af misfostre.

Dekadencens tilgang til verden er smagende. Den differentierer i æstetiske kategorier, i psykologiske nuancer, og forviser i denne bevægelse etikken til æstetikken, det superpositionelle til det juxtapositionelle, det virkelige til det uvirkelige for til slut at lade denne opløsningens kehraus munde ud i et arbitrært forhold mellem tegn og betydning, mening og form.

I et snit ned gennem historien konstaterer Jankélévitch tilstedeværelsen af dekadencens kræftsvulst i Vesterlandets tænkning, kunst og arkitektur, i Kyrenaikernes filosofi såvel som i Mahlers musik; selvfølgeligt kombineres mellem det uendeligt små og det uendeligt store, mellem koleraturariens ekvilibrisme og kapitalismens hovedløse produktion. Men det er samtidig denne tilgang, der bliver artiklens svaghed, fordi den ikke forbindes med en historisk analyse af årsagerne til, at dekadencen i bestemte perioder ikke blot er mulighed og fristelse, men også, om ikke en hel epokes, så dog bestemte kulturbærende lags selvforståelse, livsholdning og realitet. Der er i artiklen ikke gjort noget forsøg på at fremstille dekadencebegrebets opkomst, dets udviklingshistorie eller forudsætninger, dets mulige sammenhæng med en tidsalders civilisationskri- 
tik og -pessimisme. Kan man end finde påfaldende lighedstræk mellem senantikkens og århundredskiftets kunstneriske formsprog - de ciselerede og ornamenterede beskrivelser, metaforernes overflod, synonymkædernes redundans, detaljens selvstændiggørelse under prisgivelse af syntesesøgende hierarkiske strukturer, af den tankens forening med handlingens imperativ, som er det undergørende fiat, det, der vil det nye, det grænsesprængende, fremtiden - så er det alligevel vanskeligt at godtage, at det er ét og samme dekadente beredskab i kulturen, der sætter både den sengotiske katedral, de hollandske småmestres dagliglivsskildringer, barokkens englebasser og fin-de-siècle dekadencens fascination af det kunstige.

Jankélévitch undgår egentlige historiske og epokale bestemmelser og foretrækker i stedet at tale om strukturer i kulturen. Men påvisningen af strukturligheder i selvskildringens projekt fra antikken til Richard Strauss rummer faren for at udviske de særlige historiske skikkelser, dekadencen antager. Hvordan kan man gennem en analyse af dekadencen som sådan begribe den handlingslammelse, apati og ligegyldighed, det tab af historiebevidsthed, som kendetegner de - også i egen selvforståelse - dekadente intellektuelle og kunstnere omkring århundredskiftet. Og hvor langt kommer man ved at konstatere fin-de-siècle dekadencens forkærlighed for det artificielle, det udsøgte og bizarre, dersom man ikke samtidig inddrager hele det felt af overmættelse, kedsomhed og livslede, den klangbund af revolutionsangst, demokratiforagt og had til masserne, der ligger under denne tænkning og kunst, der vender sig bort fra sin samtid i afsky og foragt. Til dette har Jankélévitch kun en generel, moralsk funderet kapitalismekritik at tilbyde.

Af ubetvivlelig kvalitet er hans fremstilling af selvbevidsthedens figur og af de mekanismer, der driver denne figur mod det partikulære, selvspejlende og kimæriske, en fremstilling, der udvikles i kendte subjekt-objekt kategorier. Påfaldende er det imidlertid, at hans artikel $i$ sin stil til en vis grad fremviser de træk, den selv afviser. Det er en stil, som undvi- 
ger en strengt kausal og logisk struktureret opbygning - uden dog hermed at blive blot og bar associativ - en stil, der, som det vævre, vekselvarme firben, han flere gange i artiklen vender tilbage til, i sine bevægelser er kendetegnet ved det springende, sprælske, behændige, en stil, der snart er i hvile, snart fortætter sig i den prægnant-skønne formulering. Også hans kategoriseringer forekommer til en vis grad at være præget af fravalg af det, han måske mest foretrækker. Set i sin helhed synes hans værk ikke at propagere en formstreng, ordnet klassisk kunst, der vidner om historiens store øjeblikke, ikke den typicitet og almenhed, han her finder gestaltet hos kunstnere som Shakespeare, Rembrandt, David og Tolstoj. Derimod nævnes de små formers skitseagtigt henkastede, blufærdigtlegende og også elegant-virtuose kunst; glimtet af lys i en uventet stund, den bevægende skønhed i et ansigts tavshed, den ukendte sanseglæde fortættet $i$ en uanseelig frase eller farve. Den kunst, der synes ham nærmest som valgslægtskab, som personlig overensstemmelse, er den kunst, der nærer rædsel for svulstighed, patetik, for følelsesoversvømmelse. Det er den ubestemte, forsvindingens kunst, anslagets og impressionens kunst, den kunst, der knapt har været til stede, før den igen er forsvundet: "Lad os [...] som forbillede tage den steppeblomst, som Liszt taler om: den sætter så svage rødder $\mathbf{i}$ sandet, at den mindste vind fører den bort. Man kalder den vindens Trolovede." 